\title{
FACTORS AFFECTING PEAK EXPIRATORY FLOW RATE AND DERIVE PREDICTIVE EQUATION IN CHILDREN OF 6-12 YEARS OF AGE OF KARAIKAL
}

Pagadpally Srinivas

1. Assistant Professor, Department of Paediatrics, Vinayaka Missions Medical College, Karaikal, Pondicherry.

\section{CORRESPONDING AUTHOR}

Dr. Pagadpally Srinivas, 72, Vellai Pillaiyar Koil Street, Kottucherry, Karaikal-609609, Pondicherry,

E-mail: sreenu77@gmail.com

Ph: 00919994854115

ABSTRACT: BACKGROUND: Peak expiratory flow rate is a simple way of assessing severity of obstructive and hyper reactive airway diseases. Reference values may be used in assessment and management of asthma in children. It is also possible to predict values of PEFR, based on age, weight and height.

\section{OBJECTIVES:}

1. Determine factors affecting Peak expiratory flow rate.

2. Derive Predictive normal values for Peak expiratory flow rate in School going children of Karaikal region.

3. Derive Predictive equations correlating Peak expiratory flow Rate with age and anthropometric measurements

METHODS: A School based, Cross-sectional study consisting of 700 school going children is undertaken to study the factors affecting the peak exploratory flow rate. Each child was examined clinically based on pre designed questionnaire. Anthropometric parameters like weight, height, chest circumference were measured. PEFR was recorded using Mini Wright's Peak flow meter.

STATISTICAL ANALYSIS: Descriptive statistical analysis has been carried out in the present study ${ }^{[69,70]}$. Results on continuous measurements are presented on Mean \pm SD (Min-Max) and results on categorical measurements are presented in Number (\%). Significance is assessed at 5 $\%$ level of significance. Analysis of variance and student $t$ test has been used to find the significance of PEFR between age, gender and BMI. Pearson correlation has been used to find the significant relationship between PEFR and anthropometric parameters. Prediction equations by regression analysis is carried out. The Statistical software namely SPSS 15.0, Stata 8.0, MedCalc 9.0.1 and Systat 11.0 were used for the analysis of the data and Microsoft word and Excel have been used to generate graphs, tables etc. 
RESULTS AND CONCLUSIONS: Peak flow meter is an simple and cheap method of assessing the PEFR to assess children with chronic obstructive diseases, monitoring disease in asthma (prediction of exacerbation and monitoring therapeutic efficacy)

1. Boys have marginally higher PEFR than girls.

2. PEFR increases with age in boys and girls.

3. PEFR has good correlation with weight, height, chest circumference and BMI.

4. Predictive equations can be derived relating the PEFR with weight and height.

5. PEFR values of children of Karaikal are lesser than those of other south Indian, north Indian and western children.

\section{KEYWORDS: PEFR}

INTRODUCTION: Peak expiratory flow rate (PEFR) is a simple reliable way of following up children with bronchial asthma and other obstructive airway diseases. The peak flow meter is a useful instrument for monitoring PEFR in children and adults. Peak expiratory flow provides a simple quantitative and repro-ducible measure of resistance and severity of airflow obstruction. Peak expiratory flow can be measured with an inexpensive and portable peak expiratory flow meter.

An observed PEFR compared with the child's predicted value, is taken as the mean PEFR, attainable by normal children of the same ethnic origin [1], gender, age and body build. Normal values and prediction formulae have been established for children of European, America, African and Asian countries [2]. Values have been established for Indian children[3,4,5,6] as well .

\section{WHY THIS STUDY?}

The results of this study can be useful for predicting normal values and creating nomograms for children who live in our coastal region. In this study, we found that the PEFR values of the children from the town of Karaikal were lesser than other South Indian and North Indian children[3,7,8,9], and also lower than those of western studies [7,10,11,12,13,14,15]. The differences observed between the PEFR value of these children and those of other countries can be explained by factors like genetic factors, lifestyle, diet, and anthropometrical measurements as well as environmental conditions $[7,16,17,18,19]$.

\section{OBJECTIVES:}

1. Determine factors affecting Peak expiratory flow rate.

2. Derive Predictive normal values for Peak expiratory flow rate in School going children of Karaikal region.

3. Derive Predictive equations correlating Peak expiratory flow rate with age and anthropometric measurements

METHODOLGY: This study approved by the ethical committee was done from January 2007 to June 2007.

Written consent was taken from the parents for including their children in the study.

793 school children were screened in the age group of 6-12 years and 700 children formed the subjects of the study. All the children recruited were from Govt. school, Thalatheru, Karaikal. 
INCLUSION CRITERIA: School going children in the age group of 6-12 years.

\section{EXCLUSION CRITERIA:}

1. Children less than 6 years and more than 12 years.

2. Children with chronic respiratory infection were.

3. Children with Acute respiratory infection.

4. Children with any other chronic disease.

Age was taken as completed years as per the school records. Each child was interviewed for the history of any acute/chronic respiratory infection or any other chronic infection on a predesigned and pretested proforma (Annexure) and through clinical examination was performed.

The anthropometric measurements taken were weight, height and chest circumference.

WEIGHT: Weight was recorded without footwear and with light clothing.

Height: Standing height was recorded by making the child stand against a fixed calibrated rod with adjustable headrest.

CHEST CIRCUMFERENCE: Chest circumference was measured at the level of the nipple with a non stretchable measuring tape.

BMI was calculated using the formula

$$
\text { BMI }=\text { Weight } / \text { Height }^{2}
$$

PEAK EXPIRATORY FLOW RATE: PEFR was measured by Mini Wright's peak flow meter, made in England.

STATISTICAL METHODS: Descriptive statistical analysis has been carried out in the present study. Results on continuous measurements are presented on Mean \pm SD (Min-Max) and results on categorical measurements are presented in Number (\%). Significance is assessed at $5 \%$ level of significance. Analysis of variance and student $t$ test has been used to find the significance of PEFR between age, gender and BMI. Pearson correlation has been used to find the significant relationship between PEFR and anthropometric parameters. Prediction equations by regression analysis is carried out.

\section{SIGNIFICANT FIGURES}

+ Suggestive significance $0.05<\mathrm{P}<0.10$

* Moderately significant $0.01<\mathrm{P} \leq 0.05$

** Strongly significant $\quad \mathrm{P} \leq 0.01$

Statistical software: The Statistical software namely SPSS 15.0, Stata 8.0, MedCalc 9.0.1 and Systat 11.0 were used for the analysis of the data and Microsoft word and Excel have been used to generate graphs, tables etc. 
RESULTS: Study Design: A Cross-sectional study consisting of 700 school going children is undertaken to study the factors affecting the peak exploratory flow rate.

A total of 793 school going children of age 6-12 years of Govt school, Thalatheru

Karaikal were screened and 700 were studied. 392 (56\%) of these were boys and 308 (44\%) were girls.

DISCUSSION: Various national and international studies have shown the variability of PEFR with age, sex, height, chest circumference and BMI.

Pande et $\mathrm{al}^{20}$ conducted a study in 783 children (aged 6-17 years) from a school in urban Delhi and 523 children (aged 6-15 years) from another school in Nellore, Andhra Pradesh. Age, sex, height and weight were independent predictors of PEFR in children from Nellore. Age, sex and height, were independent predictors of PEFR in boys from Delhi while height alone was an independent predictor of PEFR in Delhi girls. Common prediction equations for predicting PEFR in boys and girls have been developed for both regions based on age and height. For the same height and age, boys had higher PEFR than girls The PEFRs of children from both parts of the country were similar, and were lower than those reported for American white children.

Swaminathan et al $^{7}$ measured Peak Expiratory Flow Rate (PEFR) in 345 healthy South Indian children aged 4-15 years, using the Wright mini peak flow meter. A nomogram was constructed relating PEFR to height. Prediction equations for PEFR using height alone or height, age and weight were determined for both sexes. The prediction equation for boys based on height alone was PEFR = 4.08 height $(\mathrm{cm})--284.55$ and for girls was PEFR $=3.92$ height $(\mathrm{cm})--$ 277.01. Caucasian and North Indian children but not for ethnic South Indian children

Chowgule et $\mathrm{al}^{10}$ did a study on children between age range 6 years to 15 years. The pulmonary function data was separated by sex, and classified on the basis of height and age. The mean and standard deviation for was calculated for every such variable. The lung function variables show a linear positive correlation with height and age. Boys show higher values for lung function variables than girls except for mid expiratory flow rates where girls have higher values than boys over height $140 \mathrm{~cm}$ and age $9 \mathrm{yrs}$. Stepwise regression equation was calculated using height, age and weight as independent variables. Height explained the maximum variance in lung function parameters Hence, for clinical evaluation of child's lung function, height is the most significant independent parameter in comparison to age and weight.

This study was conducted with an idea to compare the PEFR of the children of Karaikal region with various geographical locations nationally and internationally. Also the study was done with the aim of deriving predictive equations for school children of various age groups.

793 were screened and 700 school children were finally recruited for the purpose of this study. Among these $52 \%$ were boys and $42 \%$ girls. All the children studied were in the age group or 6-12 years

PEFR correlated well with age and anthropometric attributes in this study and is as follows :

In the present study PEFR correlated well with age

$(\mathrm{r}=0.667, \mathrm{p}<0.001)$

In the present study PEFR correlated well with weight

$(\mathrm{r}=0.638, \mathrm{p}<.001)$ 
In the present study PEFR correlated well with height

$(\mathrm{r}=0.679, \mathrm{p}<.001)$

In the present study PEFR correlated well with chest circumference $\quad(r=0.669, p<.001)$

In the present study PEFR correlated well with BMI

$(\mathrm{r}=0.280, \mathrm{p}<.001)$

These correlations are consistent with findings from various studies

In the present study PEFR of boys was marginally higher than that of girls.

The PEFR values of children were found to be lesser than that of other south Indian, north Indian children and also lesser compared to western children

\section{CONCLUSIONS:}

1. Peak flow meter is an simple and cheap method of assessing the PEFR to assess children with chronic obstructive diseases, monitoring disease in asthma (prediction of exacerbation and monitoring therapeutic efficacy)

2. Boys have marginally higher PEFR than girls.

3. PEFR increases with age in boys and girls.

4. PEFR has good correlation with weight, height, chest circumference and BMI.

5. Predictive equations can be derived relating the PEFR with weight and height.

6. PEFR values of children of Karaikal are lesser than those of other south Indian, north Indian and western children.

SUMMARY: 793 children of Govt. school, Thalatheru, Karaikal were screened and 700 were recruited for the study. They were screened for evidence of any acute or chronic respiratory illness using a pre-tested proforma and PEFR was recorded in normal children without evidence of any illness using the Mini Wright peak flow meter.

Anthropometric measurements like weight, height, chest circumference were taken and their correlation with PEFR was studied. Also the correlation of BMI was studied.

PEFR was found to correlate well with age, weight, height, chest circumference and BMI. Highest correlation was found to be with height. Boys had marginally higher PEFR than girls.

ACKNOWLEDGEMENT: I wish to thank my Head of Department, Dr. Vairavan for all his valuable guidance and help throughout this study ().

I wish to thank the children who took part in this study.

I wish to thank Dr. K P SURESH, Biostatistician for helping me in the statistical analysis and making some sense of the mountain of information that I collected.

I wish to thank Ram DTP centre for technical help.

\section{BIBILOGRAPHY:}

1. Patrick JM, Patel A. Ethnic differences in the growth of lung functions in children: A cross sectional study in inner-city Nottingham. Ann Hum Biol 1986; 13: 307-315 
2. Milner AD, Ingram D. Peak expiratory flow rates in children under 5 years of age. Arch Dis Child 1970;45:780-2

3. Harikumaran NR, Kesavachandran C, Sanil R, Srikumar R, Shashidhar S. Prediction equation for lung functions in south Indian children. Indian J Physiol Pharmacol 1997; 41: 390- 396.

4. Parmar VR, Kumar L, Malik SK. Normal values of peak expiratory flow rate in healthy North Indian school children, 6-16 years of age. Indian Pediatr 1977; 14: 591-594.

5. Nair RH, Kesavachandran C, Sanil R, Sreekumar R, Shashidhar S. Prediction equation for lung functions in South Indian children. Indian J Physiol Pharmacol 1997; 41: 390-396.

6. H Paramesh. Normal Peak Expiratory Flow Rate in Urban and Rural children. Indian J Paediatrics 2003; 70(5) : 375-377

7. Swaminathan S, Venkatesan P, Mukunthan R. Peak expiratory flow rate in South Indian Children. Indian Pediatr 1993; 30: 207-210.

8. Bartholomew PH, Katherine HKH, Daniel EJ. Ventilatory functions of normal children and young adults-Mexican-American, white and black III sitting height as a predictor. J Pediatr 1983; 102: 860-865.

9. Swaminathan S, Venketesan P, Mukunthan R. Peak expiratory flow rate in South Indian children. Indian Pediatr 1993; 30: 207-211.

10. Chowgule RV, Shetye VM, Parmar JR. Lung function tests in normal Indian children. Indian Pediatr 1995; 32: 185-191.

11. Mallik SK, Jindal SK. Pulmonary function tests in healthy children. Indian Pediatr 1985; 22: 677-681.

12. Bhattacharya AK, Banerjee S. Vital capacity in children and young adults of India. Indian J Med Res 1966; 54: 62-71.

13. Malik SK, Jindal SK, Sharda PK, Banga N. Peak expiratory flow rate of healthy schoolboys from Punjab. Indian Pediatr 1981; 18: 517-521.

14. Malik SK, Jindal SK, Sharda PK, Banga N. Peak expiratory flow rates of school age girls from Punjab (Second Report). Indian Pediatr 1982; 19: 161-164.

15. Singh HD, Peri S. Peak expiratory flow rates in South Indian children and adolescents. Indian Pediatr 1978; 11: 473-478.

16. Katherine HKH, Daniel EJ, Bartholomew PH, Erwin B, Virginia TRN, Nobuo T, et al. Ventilatory functions of normal children and young adults-Mexican-American, white and black Spirometry. J Pediatr 1979; 95: 14-23.

17. Patrick JM, Patel A. Ethnic differences in the growth of lung functions in children: A cross sectional study in inner-city Nottingham. Ann Hum Biol 1986; 13: 307-315.

18. Milner AD, Ingram D. Peak expiratory flow rates in children under 5 years of age. Arch Dis Child 1970;45:780-2.

19. Nairn JR, Bennett AJ, Andrew JD, MacArthur P. A study of respiratory function in normal school children. Arch Dis Child 1962;36:253-8.

20. Pande IN, Mohan A, Khilnani S, Khilnani GC. Peak expiratory flow rate in school-going children. Indian J Chest Dis Allied Sci 1997; 39: 87-95. 
Table 1: Age and gender distribution of children studied

\begin{tabular}{lllllll}
\hline \multirow{2}{*}{$\begin{array}{l}\text { Age in } \\
\text { years }\end{array}$} & \multicolumn{2}{c}{ Male } & \multicolumn{2}{c}{ Female } & \multicolumn{2}{c}{ Total } \\
\cline { 2 - 7 } & No & $\%$ & No & $\%$ & No & $\%$ \\
\hline $6-8$ & 141 & 35.9 & 111 & 36.1 & 252 & 36.0 \\
$8-10$ & 230 & 58.7 & 195 & 63.3 & 425 & 60.7 \\
$>10$ & 21 & 5.4 & 2 & 0.6 & 23 & 3.3 \\
Total & 392 & 100.0 & 308 & 100.0 & 700 & 100.0 \\
\hline
\end{tabular}

Table 2: Mean PEFR levels according to age, gender and BMI distribution

\begin{tabular}{ccc}
\hline \multirow{2}{*}{$\begin{array}{c}\text { Age, Gender and } \\
\text { BMI }\end{array}$} & \multicolumn{2}{c}{ PEFR $(\mathrm{L} / \mathrm{S})$} \\
\cline { 2 - 3 } Age in years & Significance \\
\hline $6-10$ & $166.74 \pm 44.72$ & \\
$10-15$ & $277.11 \pm 116.66$ & $\mathrm{~F}=167.66$ \\
$>15$ & $552.39 \pm 329.13$ & $\mathrm{P}<0.001^{* *}$ \\
Gender & & \\
Male & $259.63 \pm 140.54$ & $\mathrm{t}=2.872$ \\
Female & $230.16 \pm 126.94$ & $\mathrm{P}<0.001^{* *}$ \\
BMI (kg/m $\left.{ }^{2}\right)$ & & \\
Up to 15 & $213.02 \pm 85.89$ & $\mathrm{~F}=57.02$ \\
15.1-20.0 & $321.75 \pm 190.80$ & $\mathrm{P}<0.001^{* *}$ \\
$>20.0$ & $335.14 \pm 149.89$ & \\
All cases & $246.66 \pm 135.42$ & \\
\hline
\end{tabular}

Table 3: Pearson correlation of PEFR and anthropometric parameters

\begin{tabular}{lcccccc}
\hline \multirow{2}{*}{ Pair } & \multicolumn{2}{c}{ Male } & \multicolumn{2}{c}{ Female } & \multicolumn{2}{c}{ All children } \\
\cline { 2 - 7 } & r value & p value & r value & p value & r value & p value \\
\hline PEFR vs Age & 0.674 & $<0.001^{* *}$ & 0.651 & $<0.001^{* *}$ & 0.667 & $<0.001^{* *}$ \\
PEFR vs Weight & 0.594 & $<0.001^{* *}$ & 0.749 & $<0.001^{* *}$ & 0.638 & $<0.001^{* *}$ \\
PEFR vs Height & 0.721 & $<0.001^{* *}$ & 0.615 & $<0.001^{* *}$ & 0.679 & $<0.001^{* *}$ \\
PEFR vs BMI & 0.220 & $<0.001^{* *}$ & 0.457 & $<0.001^{* *}$ & 0.280 & $<0.001^{* *}$ \\
PEFR vs CC & 0.664 & $<0.001^{* *}$ & 0.675 & $<0.001^{* *}$ & 0.669 & $<0.001^{* *}$ \\
\hline
\end{tabular}


Table 4: Prediction equation for predicting the PEFR

\begin{tabular}{|r|l|l|l|}
\hline $\begin{array}{r}\text { Sl } \\
\text { no }\end{array}$ & \multicolumn{1}{|c|}{ Male } & \multicolumn{1}{|c|}{ Female } & \multicolumn{1}{c|}{ All children } \\
\hline 1 & $\begin{array}{l}\text { PEFR=7.32*height-689.99; } \\
\mathrm{R}^{2}=52.00\end{array}$ & $\begin{array}{l}\text { PEFR=6.40*height-596.71 } \\
\mathrm{R}^{2}=37.9\end{array}$ & $\begin{array}{l}\text { PEFR=6.99*height-658.97 } \\
\mathrm{R}^{2}=46.1\end{array}$ \\
\hline 2. & $\begin{array}{l}\text { PEFR=36.67*age-137.53 } \\
\mathrm{R}^{2}=45.4\end{array}$ & $\begin{array}{l}\text { PEFR=40.28*age-191.06 } \\
\mathrm{R}^{2}=42.4\end{array}$ & $\begin{array}{l}\text { PEFR=38.12*age-159.92 } \\
\mathrm{R}^{2}=44.5\end{array}$ \\
\hline 3. & $\begin{array}{l}\text { PEFR=13.63*CC-560.55 } \\
\mathrm{R}^{2}=44.0\end{array}$ & $\begin{array}{l}\text { PEFR=15.55*C-690.35 } \\
\mathrm{R}^{2}=45.6\end{array}$ & $\begin{array}{l}\text { PEFR=14.37*CC-612.02 } \\
\mathrm{R}^{2}=44.8\end{array}$ \\
\hline 4. & $\begin{array}{l}\text { PEFR=9.055*weight+36.49 } \\
\mathrm{R}^{2}=35.3\end{array}$ & $\begin{array}{l}\text { PEFR=14.18*weight-122.28 } \\
\mathrm{R}^{2}=56.00\end{array}$ & $\begin{array}{l}\text { PEFR=10.54*weight-13.88 } \\
\mathrm{R}^{2}=40.7\end{array}$ \\
\hline
\end{tabular}

Predictive equations for boys and girls of Karaikal:

\begin{tabular}{|c|c|c|c|}
\hline $\begin{array}{l}\text { Sl } \\
\text { No }\end{array}$ & Male & Female & All children \\
\hline 1 & $\begin{array}{l}\text { PEFR=7.32*height-689.99; } \\
\mathrm{R}^{2}=52.00\end{array}$ & $\begin{array}{l}\text { PEFR }=6.40 * \text { height }-596.71 \\
\mathrm{R}^{2}=37.9\end{array}$ & $\begin{array}{l}\text { PEFR }=6.99 * \text { height }-658.97 \\
\mathrm{R}^{2}=46.1\end{array}$ \\
\hline 2. & $\begin{array}{l}\text { PEFR=36.67*age }-137.53 \\
\mathrm{R}^{2}=45.4\end{array}$ & $\begin{array}{l}\text { PEFR=40.28*age }-191.06 \\
\mathrm{R}^{2}=42.4\end{array}$ & $\begin{array}{l}\text { PEFR=38.12*age }-159.92 \\
\mathrm{R}^{2}=44.5\end{array}$ \\
\hline 3. & $\begin{array}{l}\mathrm{PEFR}=13.63^{*} \mathrm{CC}-560.55 \\
\mathrm{R}^{2}=44.0\end{array}$ & $\begin{array}{l}\text { PEFR }=15.55 * C C-690.35 \\
\mathrm{R}^{2}=45.6\end{array}$ & $\begin{array}{l}\mathrm{PEFR}=14.37 * \mathrm{CC}-612.02 \\
\mathrm{R}^{2}=44.8\end{array}$ \\
\hline 4. & $\begin{array}{l}\text { PEFR }=9.055^{*} \text { weight }+36.49 \\
\mathrm{R}^{2}=35.3\end{array}$ & $\begin{array}{l}\text { PEFR }=14.18^{*} \text { weight }-122.28 \\
\mathrm{R}^{2}=56.00\end{array}$ & $\begin{array}{l}\text { PEFR }=10.54 * \text { weight }-13.88 \\
\mathrm{R}^{2}=40.7\end{array}$ \\
\hline
\end{tabular}

TABLE 5: COMPARISON OF PREDICTION EQUATIONS (HT) WITH OTHER INDIAN STUDIES

\begin{tabular}{|l|l|l|l|l|}
\hline Sour of data & Equipment & Age & \multicolumn{1}{c|}{ Equation } & R value \\
\hline $\begin{array}{l}\text { Godfrey et al } \\
1970, \text { London }\end{array}$ & $\begin{array}{l}\text { Mini Wright } \\
\text { peak flow } \\
\text { meter }\end{array}$ & $7-19$ & $\begin{array}{l}\text { Male: PEFR }=\left(5.288^{*} \text { Height in cm }\right)- \\
422.76 \\
\text { Female: PEFR }=\left(5.278^{*} \text { Height in cm }\right)- \\
422.34\end{array}$ & NA* \\
\hline $\begin{array}{l}\text { Swaminathan, } \\
\text { Venketesan } \\
\text { and }\end{array}$ & $\begin{array}{l}\text { Mini Wright } \\
\text { peak flow } \\
\text { meter }\end{array}$ & $4-15$ & $\begin{array}{l}\text { Male: PEFR }=\left(4.08^{*} \text { Height in cm }\right)-284.55 \\
\text { Female: PFER }=\left(3.92^{*} \text { Height in cm }\right)- \\
277.01\end{array}$ & NA* \\
\hline
\end{tabular}




\begin{tabular}{|c|c|c|c|c|}
\hline $\begin{array}{l}\text { Mukunthan, } \\
1993(5)\end{array}$ & & & & \\
\hline $\begin{array}{l}\text { Swaminathan, } \\
\text { Venketesan } \\
\text { and } \\
\text { Mukunthan, } \\
1993,\end{array}$ & $\begin{array}{l}\text { Mini Wright } \\
\text { peak flow } \\
\text { meter }\end{array}$ & $4-15$ & $\begin{array}{l}\text { Male: PEFR }=\left(2.04^{*} \text { Heigh in } \mathrm{cm}\right)+\left(4,78^{*}\right. \\
\text { age in years })+\left(2.73^{*} \text { Weight in } \mathrm{kg}\right)- \\
134.29 . \\
\text { Female: PFER }=\left(2.03^{*} \text { Height in } \mathrm{cm}\right)+ \\
\left.\left(3.18^{*} \text { Age in years }\right)+2.71 \text { Weight in } \mathrm{kg}\right)- \\
132.92\end{array}$ & $\mathrm{NA}^{*}$ \\
\hline $\begin{array}{l}\text { Parmar, } \\
\text { Kumar and } \\
\text { Malik, } \\
1977(6) \\
\end{array}$ & $\begin{array}{l}\text { Wright's peak } \\
\text { flow meter }\end{array}$ & $6-16$ & $\begin{array}{l}\text { Male: PEFR= (5.058* Height in } \mathrm{cm})- \\
408.664 \\
\text { Female: PFER }=\left(4.183^{*} \text { Height in } \mathrm{cm}\right)- \\
273.45\end{array}$ & $\mathrm{NA}^{*}$ \\
\hline $\begin{array}{l}\text { Sharma, et } \\
\text { al.,1997(8) }\end{array}$ & $\begin{array}{l}\text { Portable } \\
\text { electronic } \\
\text { lung function } \\
\text { spirometer }\end{array}$ & $10-15$ & $\begin{array}{l}\text { Male: PEFR }=\left(0.0278^{*} \text { Height in } \mathrm{cm}\right)+ \\
\left(0.1307^{*} \text { age in years }\right)+\left(0.0233^{*} \text { Weight in }\right. \\
\mathrm{kg})-2.52 \\
\text { Female: } \mathrm{PEFR}=\left(0.2382^{*} \text { Age in years }\right)+ \\
\left(0.0299^{*} \text { Weight in } \mathrm{kg}\right)-0.1716\end{array}$ & $\begin{array}{l}\text { Boys: } \\
\mathrm{R}^{2}=0.56(\mathrm{R}=0.748) \\
\text { Girls: } \mathrm{R}^{2}=0.38(\mathrm{R}= \\
0.616)\end{array}$ \\
\hline $\begin{array}{l}\text { Nair, et al., } \\
1997(9)\end{array}$ & $\begin{array}{l}\text { Computerized } \\
\text { spirometry }\end{array}$ & $5-16$ & $\begin{array}{l}\text { Male: PEFR }=\left(1.2^{*} \text { Age in years }\right)+\left(1.971^{*}\right. \\
\text { Height in } \mathrm{cm})-83.490\end{array}$ & $\mathrm{NA}^{*}$ \\
\hline $\begin{array}{l}\text { Raju, et al, } \\
2003(10)\end{array}$ & $\begin{array}{l}\text { Wright's peak } \\
\text { flow meter }\end{array}$ & $5-15$ & $\begin{array}{l}\text { Male: PEFR }=\left(4.963^{*} \text { Height in } \mathrm{cm}\right)- \\
370.050\end{array}$ & $\mathrm{R}^{2}=0.80(\mathrm{r}=0.89)$ \\
\hline $\begin{array}{l}\text { Chowgule, } \\
\text { Shetye and } \\
\text { Parmar, } \\
1995(11) \\
\end{array}$ & $\begin{array}{l}\text { Computerized } \\
\text { spirometer }\end{array}$ & $6-15$ & $\begin{array}{l}\text { Male: PEFR }=\left(0.0823^{*} \text { Height in } \mathrm{cm}\right)- \\
6.9387 \\
\text { Female: PEFR }=\left(0.0704^{*} \text { Height in } \mathrm{cm}\right)- \\
5.5233\end{array}$ & $\begin{array}{l}\text { Boys: } \\
\mathrm{R}^{2}=0.58(\mathrm{R}=0.76) \\
\text { Girls: } \mathrm{R}^{2}=0.41(\mathrm{R}= \\
0.64)\end{array}$ \\
\hline $\begin{array}{l}\text { Malik, et al., } \\
1981 \& 1982 \\
(15-16)\end{array}$ & $\begin{array}{l}\text { Wright's peak } \\
\text { flow meter }\end{array}$ & $5-16$ & $\begin{array}{l}\text { Male: PEFR }=\left(4.92^{*} \text { Height in } \mathrm{cm}\right)-368.89 \\
\text { Female: } \mathrm{PEFR}=\left(4.9^{*} \text { height in } \mathrm{cm}\right)-371.8\end{array}$ & $\begin{array}{l}\text { Boys: } \\
\mathrm{R}^{2}=0.58(\mathrm{R}=0.76) \\
\text { Girls: } \mathrm{R}^{2}=0.45(\mathrm{R}= \\
0.67)\end{array}$ \\
\hline $\begin{array}{l}\text { Pande et al., } \\
1997(14)\end{array}$ & $\begin{array}{l}\text { Mini Wright's } \\
\text { peak flow } \\
\text { meter }\end{array}$ & \begin{tabular}{|l}
$6-17$ \\
(Delhi) 6 \\
-15 \\
(Nellore) \\
\end{tabular} & $\begin{array}{l}\text { Male: PEFR }=\left(11.972^{*} \text { Age in years }\right)+ \\
\left(2.969^{*} \text { Height in cm }\right)-274.628 \\
\text { Female: PEFR }=\left(7.843^{*} \text { Age in years }\right)+ \\
\left(2.905^{*} \text { Height in } \mathrm{cm}\right)-\end{array}$ & $\begin{array}{l}\text { Boys: } \mathrm{R}^{2}=0.645(\mathrm{R}= \\
0.803) \mathrm{SEE}=46.39\end{array}$ \\
\hline $\begin{array}{l}\text { Present } \\
\text { study }\end{array}$ & $\begin{array}{l}\text { Mini } \\
\text { Wright's }\end{array}$ & $6-12$ & $\begin{array}{l}\text { Male:PEFR=7.32*height-689.99; ; } \\
\text { Female: PEFR=6.40*height-596.71 }\end{array}$ & $\begin{array}{l}\text { Boys: } \mathrm{R}^{2}=52.00 \\
\text { Girls : } \mathrm{R}^{2}=37.9\end{array}$ \\
\hline
\end{tabular}


TABLE 6: COMPARISON OF PREDICTION EQUATIONS WITH OTHER PARAMETERS

\begin{tabular}{|c|c|c|c|c|}
\hline Sour of data & Equipment & Age & Equation & $R$ value \\
\hline $\begin{array}{l}\text { Vijayan, et } \\
\text { al.,2000(4) } \\
\text { Girls = 223) } \\
\text { Done in } \\
\text { Chennai, } \\
\text { South India }\end{array}$ & $\begin{array}{l}\text { Dry rolling } \\
\text { spirometer }\end{array}$ & 7-19 & $\begin{array}{l}\text { Male: PEFR }=\left(0.063^{*} \text { Height in } \mathrm{cm}\right)+\left(0.061^{*}\right. \\
\text { Weight in kg })-6.784 \\
\text { Female: PEFR }=\left(0.20^{*} \text { Height in } \mathrm{cm}\right)+ \\
\left(0.070^{*} \text { Weight in } \mathrm{kg}\right)-1.613\end{array}$ & $\mathrm{NA}^{*}$ \\
\hline \begin{tabular}{|l|} 
Swaminathan, \\
Venketesan \\
and \\
Mukunthan, \\
1993 \\
\end{tabular} & $\begin{array}{l}\text { Mini Wright } \\
\text { peak flow } \\
\text { meter }\end{array}$ & $4-15$ & $\begin{array}{l}\text { Male: } \text { PEFR }=\left(2.04^{*} \text { Height in } \mathrm{cm}\right)+\left(4,78^{*} \text { age }\right. \\
\text { in years })+\left(2.73^{*} \text { Weight in } \mathrm{kg}\right)-134.29 \\
\text { Female: } \mathrm{PFER}=\left(2.03^{*} \text { Height in } \mathrm{cm}\right)+\left(3.18^{*}\right. \\
\text { Age in years })+2.71 \text { Weight in } \mathrm{kg})-132.92\end{array}$ & $\mathrm{NA}^{*}$ \\
\hline \begin{tabular}{|l|} 
Rajkapoor, \\
Mahajan and \\
Mahajan, \\
1997(7)
\end{tabular} & $\begin{array}{l}\text { Computerized } \\
\text { spirometry }\end{array}$ & $6-13$ & $\begin{array}{l}\text { Male: PFER }=\left(11.52^{*} \text { Age in years }\right)+ \\
\left(88.99^{*} \text { Height in } \mathrm{cm}\right)+10.44 \\
\text { Female: PFER }=\left(4.14^{*} \text { Age in years }\right)+ \\
\left(252.44^{*} \text { Height in } \mathrm{cm}\right)-140.32\end{array}$ & $\mathrm{NA}^{*}$ \\
\hline $\begin{array}{l}\text { Sharma, et } \\
\text { al.,1997(8) }\end{array}$ & $\begin{array}{l}\text { Portable } \\
\text { electronic } \\
\text { lung function } \\
\text { spirometer }\end{array}$ & $10-15$ & $\begin{array}{l}\text { Male: PEFR }=\left(0.0278^{*} \text { Height in } \mathrm{cm}\right)+\left(0.1307^{*}\right. \\
\text { age in years })+\left(0.0233^{*} \text { Weight in } \mathrm{kg}\right)-2.52 \\
\text { Female: PEFR }=\left(0.2382^{*} \text { Age in years }\right)+ \\
\left(0.0299^{*} \text { Weight in } \mathrm{kg}\right)-0.1716\end{array}$ & $\begin{array}{l}\text { Boys: } \\
\mathrm{R}^{2}=0.56(\mathrm{R}= \\
0.748) \text { Girls: } \mathrm{R}^{2}= \\
0.38(\mathrm{R}=0.616)\end{array}$ \\
\hline $\begin{array}{l}\text { Nair, et al., } \\
1997(9)\end{array}$ & $\begin{array}{l}\text { Computerized } \\
\text { spirometry }\end{array}$ & $5-16$ & $\begin{array}{l}\text { Male: PEFR }=\left(1.2^{*} \text { Age in years }\right)+\left(1.971^{*}\right. \\
\text { Height in } \mathrm{cm})-83.490\end{array}$ & $\mathrm{NA}^{*}$ \\
\hline $\begin{array}{l}\text { Chowgule, } \\
\text { Shetye } \\
\text { and Parmar, } \\
1995\end{array}$ & $\begin{array}{l}\text { Computerized } \\
\text { spirometer }\end{array}$ & $6-15$ & $\begin{array}{l}\text { Male: PEFR }=\left(0.0706^{*} \text { Height in } \mathrm{cm}\right)+\left(0.0706^{*}\right. \\
\text { weight in } \mathrm{kg})-5.8592 \\
\text { Female: } \mathrm{PEFR}=\left(0.0303^{*} \text { Height in } \mathrm{cm}\right)+ \\
\left(0.0308^{*} \text { Weight in } \mathrm{kg}\right)+\left(0.1219^{*} \text { Age in years }\right) \\
-2.3075\end{array}$ & $\begin{array}{l}\text { Boys: } \\
\mathrm{R}^{2}=0.58(\mathrm{R}= \\
0.76) \text { Girls: } \mathrm{R}^{2}= \\
0.45(\mathrm{R}=0.67)\end{array}$ \\
\hline $\begin{array}{l}\text { lhowgule, } \\
\text { Shetye } \\
\text { and Parmar, } \\
1995\end{array}$ & $\begin{array}{l}\text { Computerized } \\
\text { spirometer }\end{array}$ & $6-15$ & $\begin{array}{l}\text { Female: PEFR }=(0.0539 * \text { Height in } \mathrm{cm})+ \\
\left(0.1084^{*} \text { Age in years }\right)-4.4358\end{array}$ & $\begin{array}{l}\mathrm{R}^{2}=0.44(\mathrm{R}= \\
0.66)\end{array}$ \\
\hline $\begin{array}{l}\text { Pande et al., } \\
1997(14)\end{array}$ & $\begin{array}{l}\text { Mini Wright's } \\
\text { peak flow } \\
\text { meter }\end{array}$ & \begin{tabular}{|l|}
$6-17$ \\
(Delhi) 6 \\
-15 \\
(Nellore) \\
\end{tabular} & $\begin{array}{l}\text { Male: PEFR }=\left(11.972^{*} \text { Age in years }\right)+\left(2.969^{*}\right. \\
\text { Height in cm })-274.628 \\
\text { Female: PEFR }=\left(7.843^{*} \text { Age in years }\right)+\left(2.905^{*}\right. \\
\text { Height in cm })-243.833\end{array}$ & $\begin{array}{l}\text { Boys: } R^{2}=0.645 \\
(R=0.803) \mathrm{SEE}= \\
46.39\end{array}$ \\
\hline $\begin{array}{l}\text { Present } \\
\text { study, } \\
\text { Karaikal. }\end{array}$ & $\begin{array}{l}\text { Wright's peak } \\
\text { flow meter }\end{array}$ & $6-12$ & $\begin{array}{l}\text { Male PEFR=36.67*age- } 137.53 \\
\mathrm{R}^{2}=45.4 \\
\text { Female: PEFR PEFR=40.28*age-191.06; } \\
\mathrm{R}^{2}=42.4 \\
\text { Male: } \text { PEFR=9.055*weight }+36.49 \\
\mathrm{R}^{2}=35.3 \\
\text { Female: PEFR }=14.18^{*} \text { weight }-122.28 \\
\mathrm{R}^{2}=56.00\end{array}$ & \\
\hline
\end{tabular}




\section{ORIGINAL ARTICLE}

\begin{tabular}{|l|l|l|l|}
\hline & & $\begin{array}{l}\text { Male: } \text { PEFR=13.63*CC-560.55 } \\
\mathrm{R}^{2}=44.0 \\
\text { Female: PEFR=15.55*C-690.35 } \\
\mathrm{R}^{2}=45.6\end{array}$ & \\
\hline
\end{tabular}

TABL E 7: Comparison of PEFR (L/min) of present study with other studies

\begin{tabular}{|c|l|l|l|l|l|l|l|l|l|}
\hline Height & \multicolumn{2}{|l|}{ Present Series } & \multicolumn{2}{c|}{$\begin{array}{c}\text { Swaminathan } \\
\text { et al (2) }\end{array}$} & \multicolumn{2}{c|}{$\begin{array}{c}\text { Malik et al } \\
(64)\end{array}$} & $\begin{array}{c}\text { Paramesh H } \\
(71)\end{array}$ & \multicolumn{2}{|c|}{$\begin{array}{c}\text { Godfrey et al } \\
(4)\end{array}$} \\
\hline cm & Boys & Girls & Boys & Girls & Boys & Girls & Common value & Boys & Girls \\
\hline 120 & $\mathbf{1 8 8}$ & $\mathbf{1 7 1}$ & 205 & 193 & 222 & 216 & 200 & 212 & 211 \\
\hline 140 & $\mathbf{2 9 0}$ & $\mathbf{2 6 8}$ & 286 & 272 & 320 & 314 & 300 & 318 & 317 \\
\hline 160 & $\mathbf{3 4 2}$ & $\mathbf{3 3 6}$ & 368 & 358 & 418 & 412 & 400 & 423 & 422 \\
\hline
\end{tabular}

Fig 1: Pie graph showing distribution of girls and boys in the study

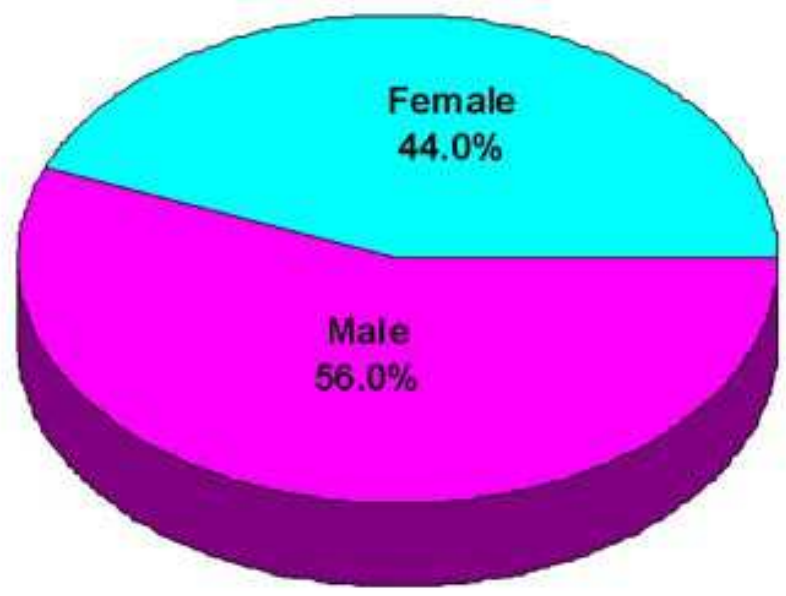

Gender 
Fig 2: Bar Graph showing BMI distribution of children studied

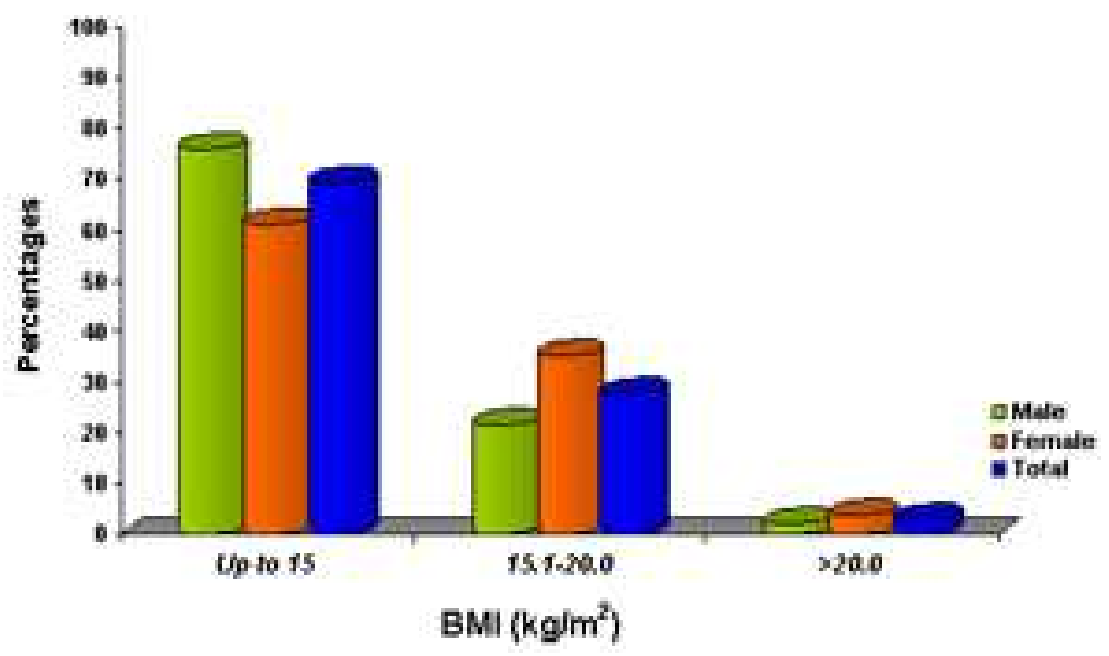

Fig 4: Bar Graph showing mean pattern of PEFR in relation to age

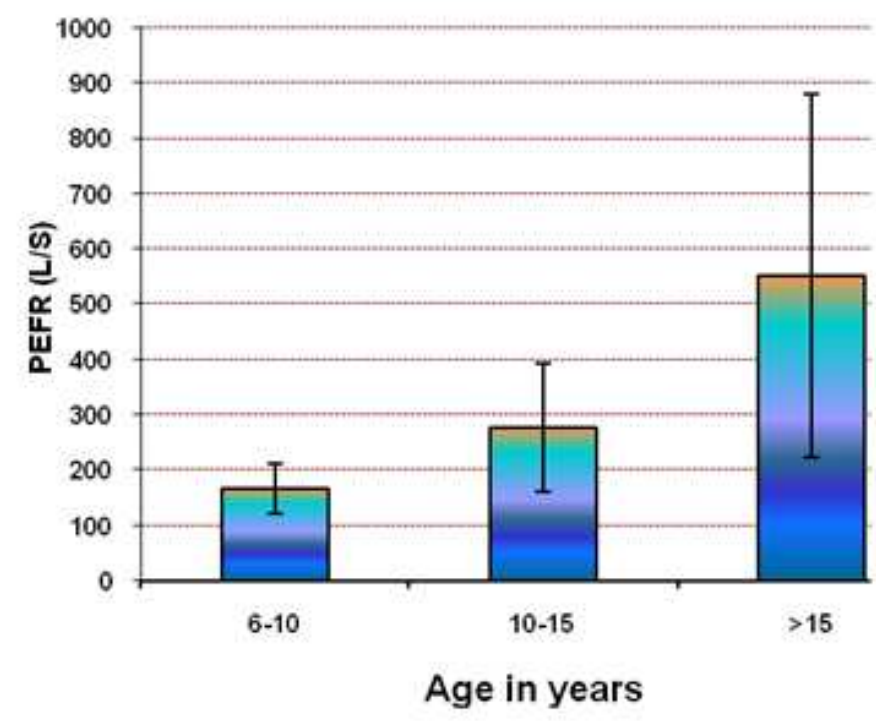


Fig 5: Bar Graph showing mean pattern of PEFR in relation to Gender

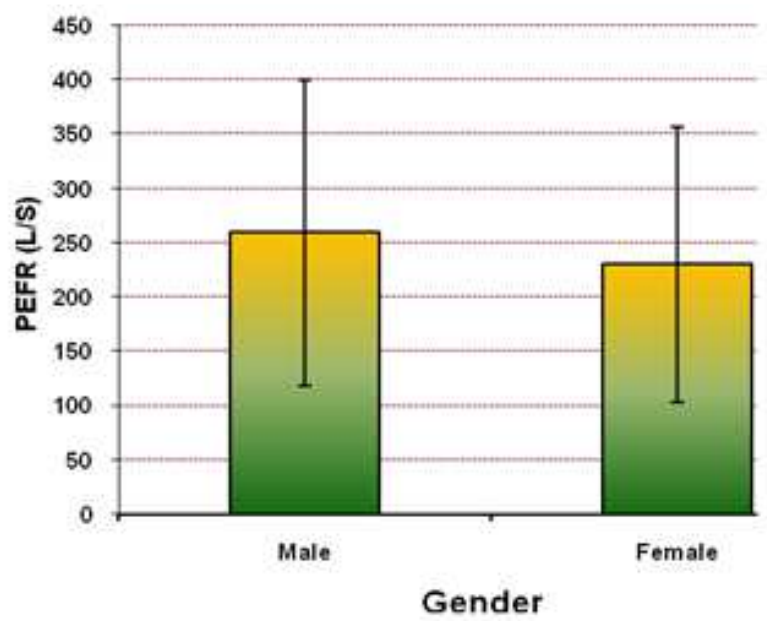

Fig 6: Bar Graph showing mean pattern of PEFR in relation to BMI
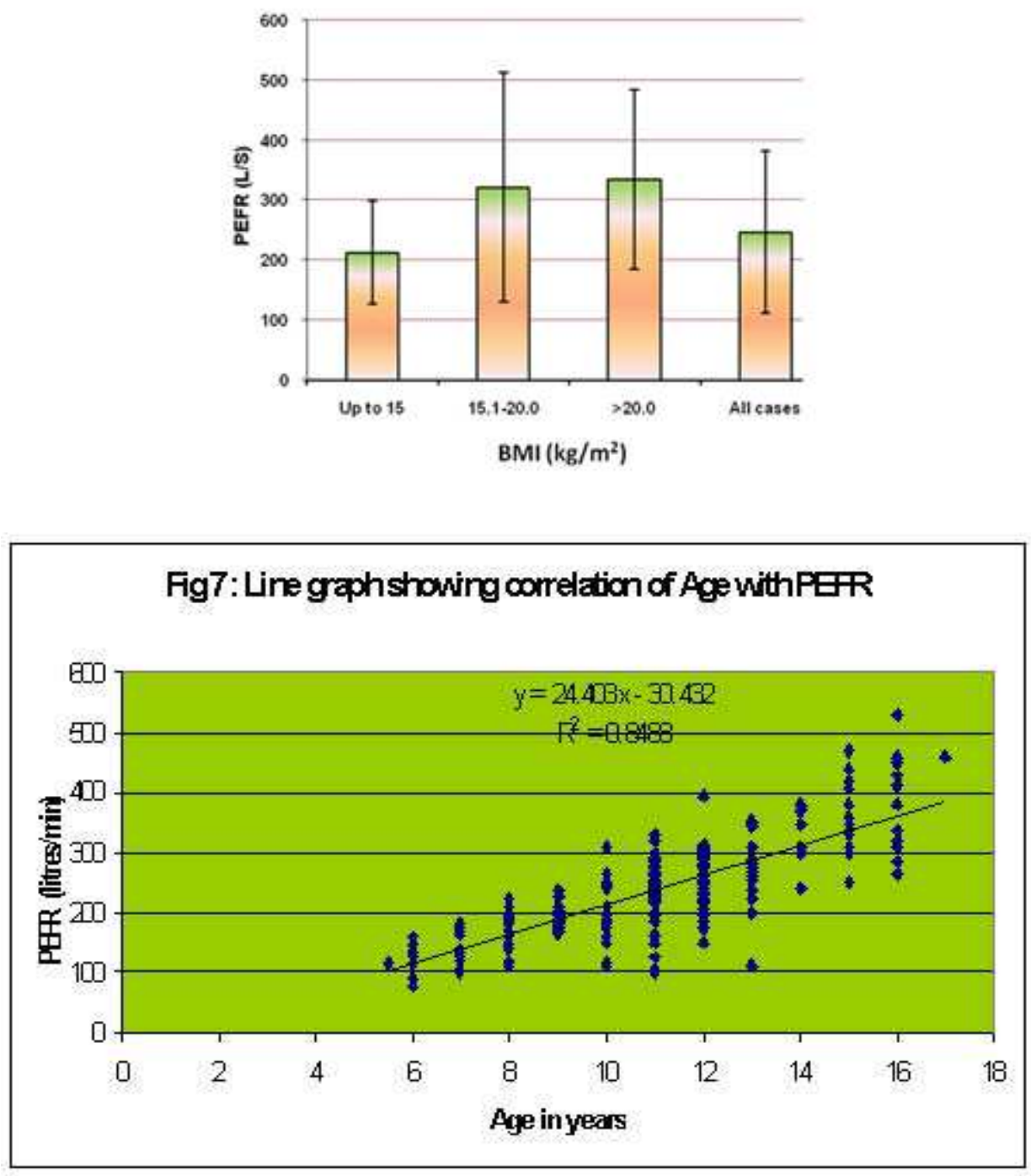


\section{ORIGINAL ARTICLE}
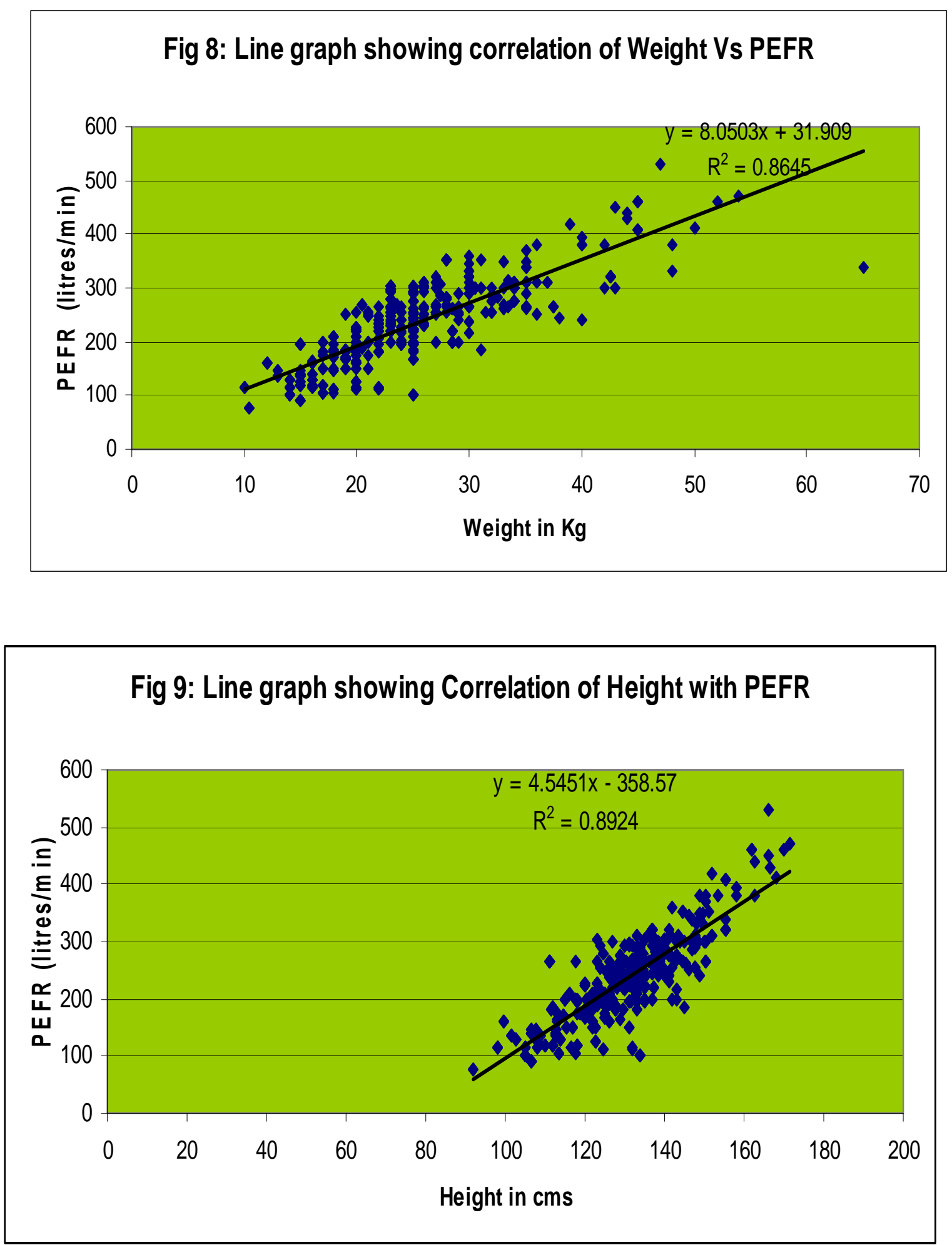


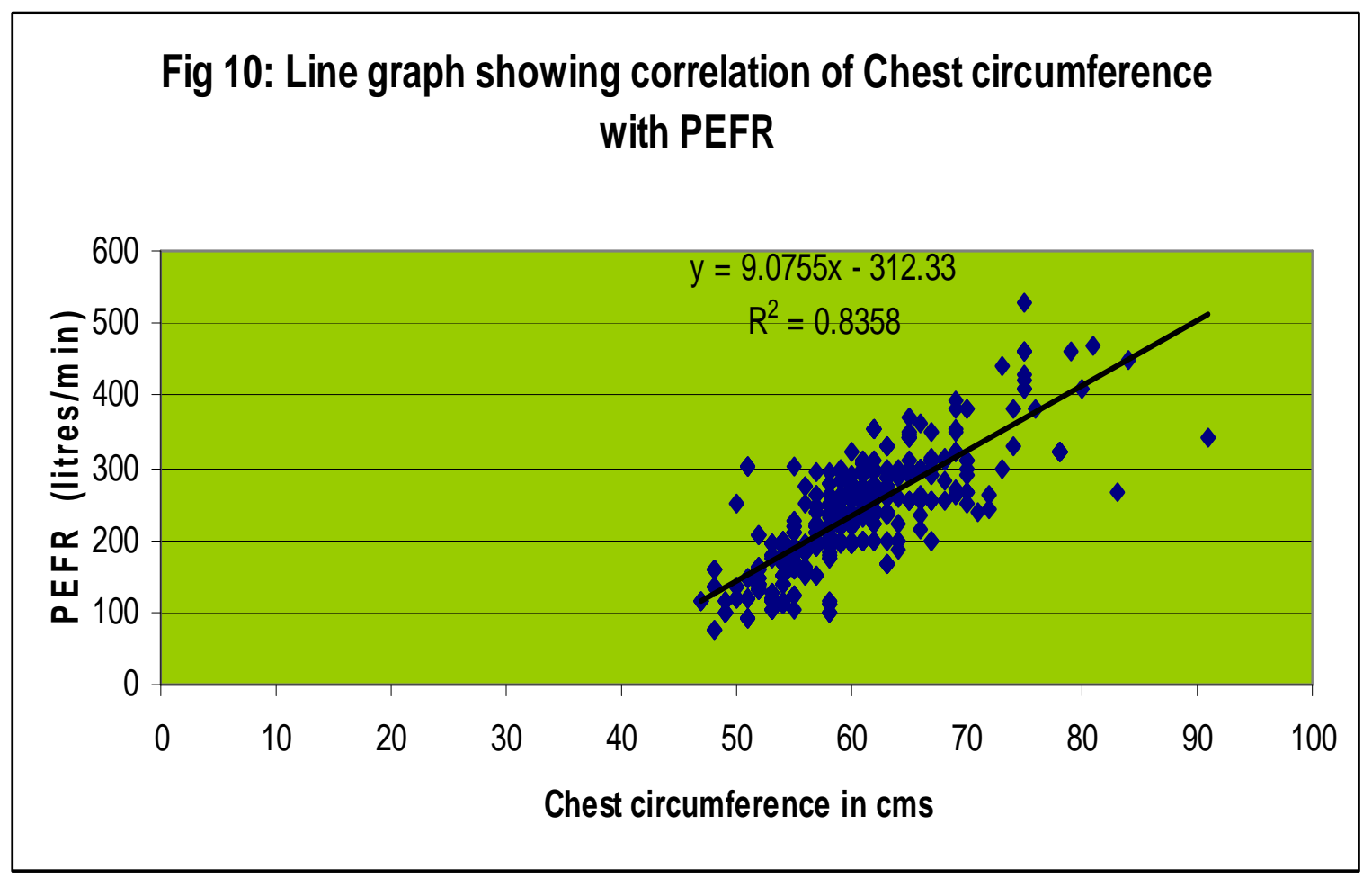

